Open Access

\title{
The impact of corporate characteristics on the financial decisions of companies: evidence on funding decisions by Italian SMES
}

\author{
Matteo Rossi ${ }^{1^{*}}$ D, Rosa Lombardi ${ }^{2}$, Dario Siggia ${ }^{3}$ and Nadia Oliva ${ }^{4}$
}

\author{
* Correspondence: \\ mrossi@unisannio.it \\ ${ }^{1}$ University of Sannio, Via delle \\ Puglie, 82, 82100 Benevento, Italy \\ Full list of author information is \\ available at the end of the article
}

\begin{abstract}
Small and medium enterprises (SMEs) represent a large percentage of the corporate tissue of developed countries, but they do not have adequate attention. In fact, various researchers have focused their studies on larger and well-known companies. This paper aims to investigate the impact of corporate characteristic on the financial choices of SMEs, with a specific focus on agro-food micro companies. Access to finance is vital in business start-up, development and growth for SMEs, all with very different needs and facing different challenges in terms of finance compared to large companies. The lack of equity invested in small enterprises makes them more dependent on other external sources (e.g. bank loans, overdraft, factoring and leasing). The limitations of the paper are the result of its very nature: it is a largely conceptual paper. Empirical research is therefore needed to test and validate the essentially preliminary framework.
\end{abstract}

Keywords: Capital structure, Internal source, External source, Bank loans, Agro-food firms, SMES

\section{Background}

Small and medium enterprises (SMEs) represent a large portion of the corporate tissue of developed countries. In fact, the 20 million European SMEs play an important role in the European economy. In 2012, they represented $99.8 \%$ of the total number of companies, and $66.5 \%$ of all European jobs for that year (European Commission 2013b). During 2012, the SME sector as a whole contributed to $57.6 \%$ of the gross value added (Table 1) generated by the private, non-financial economy in Europe 2012 (Eurostat 2013).

The role of SMEs is crucial for recovery of the European economy: their number, employment capacity and added value constitute a large share of the European economy. Providing the right conditions in which SMEs can flourish is paramount for ensuring a sustained recovery and achieving prosperity for all EU citizens.

Recent studies on SMEs and their contribution to growth have shown that framework conditions within which they operate, and the entrepreneurial culture are key factors in establishing the extent of SME performance and consequently their contribution to macroeconomic growth. Even in the presence of a strong entrepreneurial culture, however,

\section{空 Springer}

(c) 2016 Rossi et al. Open Access This article is distributed under the terms of the Creative Commons Attribution 4.0 International License (http://creativecommons.org/licenses/by/4.0/), which permits unrestricted use, distribution, and reproduction in any medium, provided you give appropriate credit to the original author(s) and the source, provide a link to the Creative Commons license, and indicate if changes were made. 
Table 1 Companies, employment and gross value added of SMEs in the EU-27, 2012

\begin{tabular}{|c|c|c|c|c|c|c|}
\hline & Micro & Small & Medium & SMES & Large & Total \\
\hline \multicolumn{7}{|c|}{ Number of enterprises } \\
\hline Number & $18,783,480$ & $1,349,730$ & 222,628 & $20,355,839$ & 43,454 & $20,399,291$ \\
\hline$\%$ & $92.1 \%$ & $6.6 \%$ & $1.1 \%$ & $99.8 \%$ & $0.2 \%$ & $100 \%$ \\
\hline \multicolumn{7}{|l|}{ Employment } \\
\hline Number & $37,494,458$ & $26,704,352$ & $22,651,906$ & $86,814,717$ & $43,787,013$ & $130,601,730$ \\
\hline$\%$ & $28.7 \%$ & $20.5 \%$ & $17.3 \%$ & $66.5 \%$ & $33.5 \%$ & $100 \%$ \\
\hline \multicolumn{7}{|c|}{ Value added at factor costs } \\
\hline Million Euros & $1,242,724$ & $1,076,388$ & $1,076,270$ & $3,395,383$ & $2,495,926$ & $5,891,309$ \\
\hline$\%$ & $21.1 \%$ & $18.3 \%$ & $18.3 \%$ & $57.6 \%$ & $42.4 \%$ & $100 \%$ \\
\hline
\end{tabular}

Source: Eurostat, 2013

SMEs would struggle to perform if basic framework conditions were not present (European Commission 2013a).

All these figures highlight the importance of these companies, but they are not always given the right attention. The emphasis on big companies undermined the development of young and small companies that do not have access to public markets (Zingales 2000).

Many financial scholars have investigated debt policy decisions made in companies. There are also many empirical studies on the financing decisions of large and listed companies (Bradley et al. 1984; Auberbach 1985; Friend and Hasbrouck 1988; Titman and Wessels 1988; Barclay et al. 1995; Rajan and Zingales 1995; Graham 1996; Chen et al. 1998; Wald 1999; Rossi et al. 2012; Rossi 2014), but the scientific community has only recently started to study the financial structures of the small companies. In spite of this, there are a considerable number of relevant empirical works worldwide such as Constand et al. (1989), van der Wijst (1989), Walker (1989a, b), Holmes and Kent (1991), Chittenden et al. (1996), Calcagnini and Iacobucci (1997), Hamilton and Fox (1998), Jordan et al. (1998), Michaelas et al. (1999) and López and Aybar (2000).

Following this research, this paper aims to study the determinants of the financial choices of the SMEs. The structures of the remainder of the paper are as follows: "Financing lifecycle: financial sources for companies" section describes the financing lifecycle and internal-external financial resources. "The Italian agro-food system" section presents the Italian agro-food system and the Italian agro-firm structure. "Access to finance for Italian SMEs" section explains the main problem related to access to finance for Italian small companies. The research methods and results are discussed in "Methods" section. "Conclusions and research limitations" section concludes the paper.

\section{Financing lifecycle: financial sources for companies}

The absence of economic capital is one of the most important obstacles to growth. The management of the capital factor, from acquisition until the time of its use, will require a decision-making process focused on quantitatively and qualitatively capital resources observed both in their origin-sources-and in their destination-uses. Funds differ in various stages of a company's life cycle (Fig. 1).

In the start-up phase, the family of the owner and/or business angels are the main investors of a new company. Start-up financing is used for product development and 


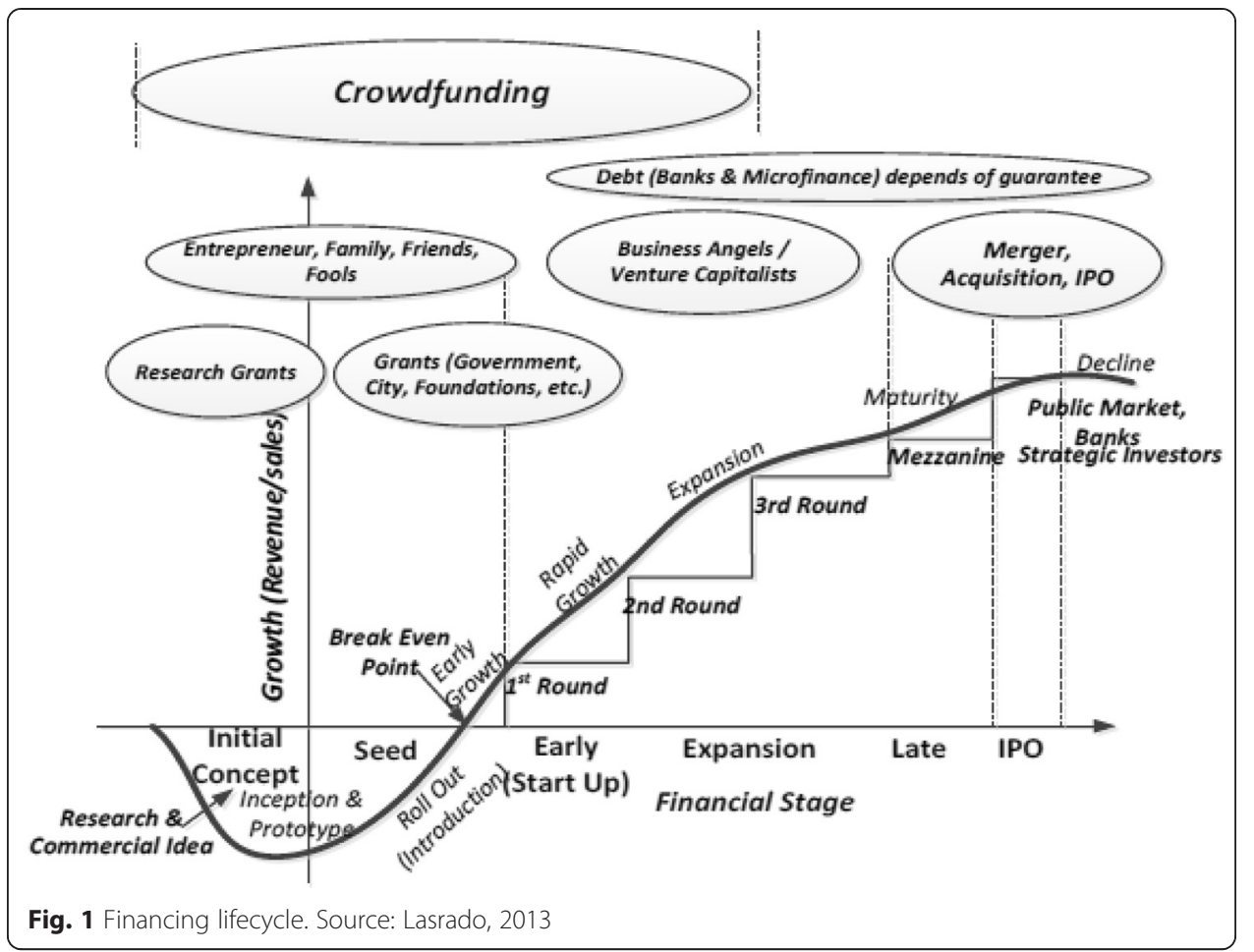

initial marketing activities. Companies may still be in their creation phase or have just started operations, without having sold their product. At this stage, money is important to pursue R\&D activities. When the product has taken form, a certain number of venture capitalists will join the company: they want to set up the company. After training, the company has developed its product and it requires more financial resources in order to market it. The company that has not yet generated any profit as the expansion-development step is a high progression process. At this stage, capital is used to increase production, to develop new services/products, to finance acquisitions and/or to increase the working capital of the business (Rossi, 2015).

Companies require different forms of capital in different stages of their life. Financial resources can be classified into external sources and internal sources; the internal sources include all the financial resources from inside the business, external sources include all of the financial tools from outside the business (Fig. 2).

Internal finance tends to be the cheapest form of finance since a business does not need to pay interest on the money. However, it may not be able to generate the money that the company is looking for, especially in the case of large amounts. There are three internal sources of finance:

- Retained profits

- Sale of existing assets

- Cut down in stock levels

External sources can be divided into long-term, medium-term and short-term. Shortterm financing has a repayment period of less than 1 year. Medium-term financing 


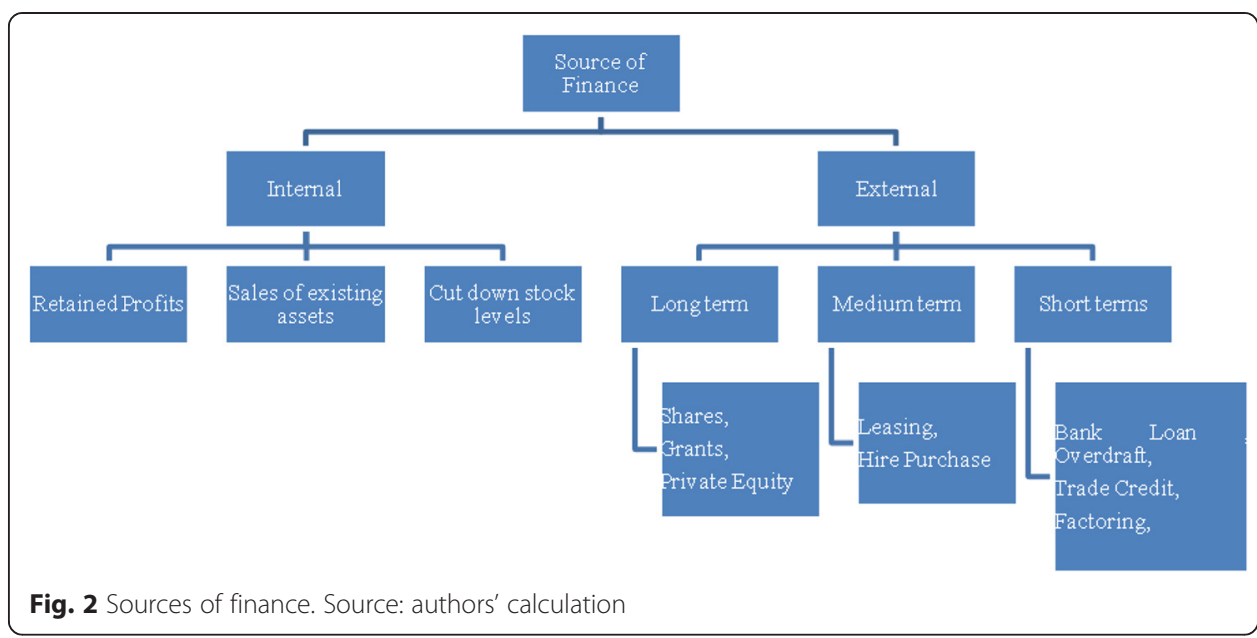

includes those with a maturity period of more than 1 year but less than 5 years. Longterm financing includes those with a maturity period of 5 years or more.

There are a lot external sources of finance:

- Bank loan or overdraft

- Trade credit

- Factoring

- Leasing

- Hire purchase

- Shares

- Long-term bank loans

- Grants

- Private equity, venture capital, business angels

The use of external financial resources is linked to the main of internal resources (Table 2).

In fact, internal resources are limited in volume, and this requires external investors. External financing can help jump-start of business, but it also has drawbacks (Table 3).

Starting from the seminal papers of Modigliani and Miller (1958, 1963), a lot of financial research has focused attention on optimal capital structure. One of the most important research projects was conducted by Myers and Majluf (1984); they argued that a hierarchy exists in loan funds for companies. Due to information-related asymmetries, companies prefer internal than to external capital sources. The limitation of

Table 2 The advantages and disadvantages of internal sources

\begin{tabular}{ll}
\hline Advantages & Disadvantages \\
\hline Capital available & Expensive: is not tax-deductible \\
No interest & No increase of capital \\
Spares credit line & Not as flexible as external financing \\
No control procedures regarding creditworthiness & Losses are not tax-deductible \\
No influence of third parties & Limited in volume \\
\hline
\end{tabular}

Source: author's calculation 
Table 3 The advantages and disadvantages of external sources

\begin{tabular}{ll}
\hline Advantages & Disadvantages \\
\hline Faster growth & Loss of ownership \\
Greater economies of scale & Loss of control \\
Leveraged return & Cost \\
& Cash flow \\
\hline
\end{tabular}

Source: author's calculation

internal resources led the owners of SMEs to select external capital sources. In these cases, they chose short-term debt, because it does not reduce managers' operability.

\section{The Italian agro-food system}

The Italian food industry is a fundamental part of the country's economic system and represents an important sector of its manufacturing industry (Crescimanno et al. 2015). In recent years, the food industry has been affected by the wider decline and loss of competitiveness of the Italian industry.

\section{Product of designated origin}

Italy continues to maintain the largest share in the market for protected designation of origin (PDO) and protected geographical indication (PGI) products in the EU (that is 1167, including also traditional specialty guaranteed (TSG)), recording a further increase to 252. Most of the specialties deal with fruit and vegetables and cereals (almost $40 \%$ ), cheese (18\%), extra virgin olive oil (17.6\%) and cold meats (over 14\%). Mozzarella and pizza napoletana are the only recognized Italian traditional specialty guaranteed (across the EU, they amount to 38). The regions with the most PDO and PGI products were Emilia-Romagna and Veneto, with 35 and 33 products, respectively.

In 2013, there were 80,435 certified operators, of these, $91.2 \%$ were exclusively involved in production activities and $6.6 \%$ in product transformation; the remaining $2.2 \%$ performed both activities (ISTAT, 2014). Among producers (75,156 units), the cheese sector was rather highly represented (27,190 units, with the equivalent of $36.2 \%$ of the total), along with olive oil (19,083 or $25.4 \%)$ and fruit, vegetables and cereals $(17,076$ or $22.7 \%)$. Transformers (7090 units) were also more frequent in the extra virgin olive oil (1863 or $26.3 \%$ of the total), cheese (1691 or $23.9 \%$ ) and fruit, vegetables and cereals (1165 or $16.4 \%$ ) sectors. Overall, the stable number of producers registered between 2012 and 2013 was the result of a fall in Northern (-4.2\%) and Central areas $(-1 \%)$ compared with a rise in South and Islands area (+7.5\%). The slight increase in the number of transformers was due to an increase in the Centre and North, exceeding the fall in the South and Islands area (Table 4).

ISMEA figures on demand for PDO/PGI products indicate a drop in domestic consumption and an increase in value, caused by higher average retail prices. The number of the Italian quality wines increased in both PDO and PGI. There are 476 registrations considering the Denominazione di Origine Controllata e Garantita (DOCG), Denominazione di Origine Controllata (DOC) and IGT wines. With a production of 15.5 million hectolitres of DOC-DOCG at the end of the decade, they account for $40 \%$ of all wines produced in Italy. The North is still in first place in terms of quality production 
Table 4 Number of PDO and PGI products by regions-2013

\begin{tabular}{|c|c|c|c|c|c|c|}
\hline Region & Fruit, vegetables and cereals & Olive oil & Cheese & Prepared meats & Other products & Total \\
\hline Piedmont & 6 & - & 8 & 4 & 1 & 19 \\
\hline Valle d'Aosta & - & - & 2 & 2 & - & 4 \\
\hline Lombardy & 2 & 2 & 11 & 9 & 1 & 25 \\
\hline Liguria & 1 & 1 & - & - & 1 & 3 \\
\hline Trentino-Alto Adige & 3 & 1 & 5 & 2 & 1 & 12 \\
\hline Veneto & 16 & 2 & 7 & 7 & 1 & 33 \\
\hline Friuli-Venezia Giulia & 1 & 1 & 1 & 3 & - & 6 \\
\hline Emilia-Romagna & 11 & 2 & 4 & 13 & 5 & 35 \\
\hline Tuscany & 7 & 5 & 2 & 4 & 7 & 25 \\
\hline Umbria & 2 & 1 & 1 & 2 & 2 & 8 \\
\hline Marche & 2 & 1 & 2 & 4 & 2 & 11 \\
\hline Lazio & 7 & 4 & 3 & 4 & 7 & 25 \\
\hline Abruzzo & 2 & 3 & - & 1 & 3 & 9 \\
\hline Molise & - & 1 & 1 & 2 & 2 & 6 \\
\hline Campania & 11 & 5 & 3 & - & 2 & 21 \\
\hline Puglia & 6 & 5 & 3 & - & 2 & 16 \\
\hline Basilicata & 4 & 1 & 3 & - & 1 & 9 \\
\hline Calabria & 4 & 3 & 1 & 4 & 2 & 14 \\
\hline Sicily & 15 & 6 & 4 & 1 & 2 & 28 \\
\hline Sardinia & 1 & 1 & 3 & - & 2 & 7 \\
\hline Italy ${ }^{a}$ & 100 & 43 & 44 & 36 & 29 & 252 \\
\hline
\end{tabular}

Source: INEA, 2014

${ }^{a}$ Some products are inter-regional, so, the total of PDO/PGI by region does not correspond to the total for Italy

with 9.3 million hectolitres, or $62 \%$ of the national DOC production. Wines of controlled origin (especially red wines) continue to be among Italy's best-selling exports, with a total value of nearly 1.4 billion euro.

\section{Land market and investments in the sector}

In 2012, the Italian land market has been characterized by a fall in sales and a reduction in prices. The national average of the land value decreased by $0.1 \%$ year by year, reaching approximately $€ 20,000 /$ ha. However, reduction in real terms was stronger $(-3.1 \%)$. The main factors that have contributed to this slowdown are related to the general economic crisis and to the new scenarios that have characterized agriculture in the last decade (Trequattrini et al. 2012). In particular, the difficulty of access to credit limits the demand from the professional farmers, while uncertainties on profitability of the sector affect the activity of the non-agricultural actors (Rossi et al. 2014).

In 2012, gross fixed investments in agriculture, in real terms, have marked a $9.6 \%$ decrease considerably larger than the one registered in the previous year $(-1 \%)$. Compared with 2011, the share of agricultural investment in total investments decreased, dropping to $3.5 \%$ as did the relation with the agricultural added value (from $34.2 \%$ in 2011 to $32.4 \%$ in 2012).

In 2011, the allocation by type of asset, referring to all economic activities, showed a slight decrease for investments in crops and livestock $(-0.7 \%)$, after the positive results 
shown in the three previous years. On the other hand, other sectors show a much more negative trend with a decrease of $12.2 \%$ for transportation, $10.7 \%$ for machinery and equipment and $6.3 \%$ for non-residential buildings and other works.

Despite the downward trend compared to 2011, the amount of investments per worker in the primary sector which has increased in recent years deserves to be mentioned, essentially due to a fall in employment in the sector. As a result of the reduction of manufacturing employment, there has been an increase in the capital stock in agriculture $(+1.6 \%)$, in real terms and net of depreciation.

\section{The Italian agro-industrial system}

The agro-industrial system is made up of a number of activities through which agriculture interacts with all the sectors connected to it, up and down the supply chain: from the industry inputs (fertilizers, pesticides, animal feed, energy, etc.) to the food processing, distribution and catering industries. The agro-food sector has an estimated value of approximately 266 billion euro (almost $17 \%$ of GDP). The main contributions were approximately 28.1 billion euro from agricultural added value (VA), 25 billion euro from intermediate consumption in agriculture, 17.8 billion euro from agro-industrial investments, 25.7 billion euro from VA in the food industry, 43.8 billion euro from VA in the catering industry and 108.2 billion euro from marketing and distribution (Fig. 3).

\section{The Italian agro-firm structure}

The sixth General Agricultural Census shows a structural framework characterized by a strong decrease in the number of farms $(-32.4 \%)$ compared to 2000 and a more modest decline in UAA $(-2.5 \%)$. The phenomenon is the result of a multi-year process during which agricultural lands and farms were concentrated in a substantially smaller number of farms (Fig. 4a). It has resulted in an increase of the average farm's UAA that grows from 5.5 to 7.9 ha. Although there has been an increase in companies with larger size (more than $30 \mathrm{ha}$ ), Italian agriculture continues to be characterized by a very large number of very small companies that affect the economic performance of the sector. Companies with a standard value production of less than 8000 euro represent $62 \%$ of the total farms, and they account for only $5.3 \%$ of the total standard production of domestic agriculture

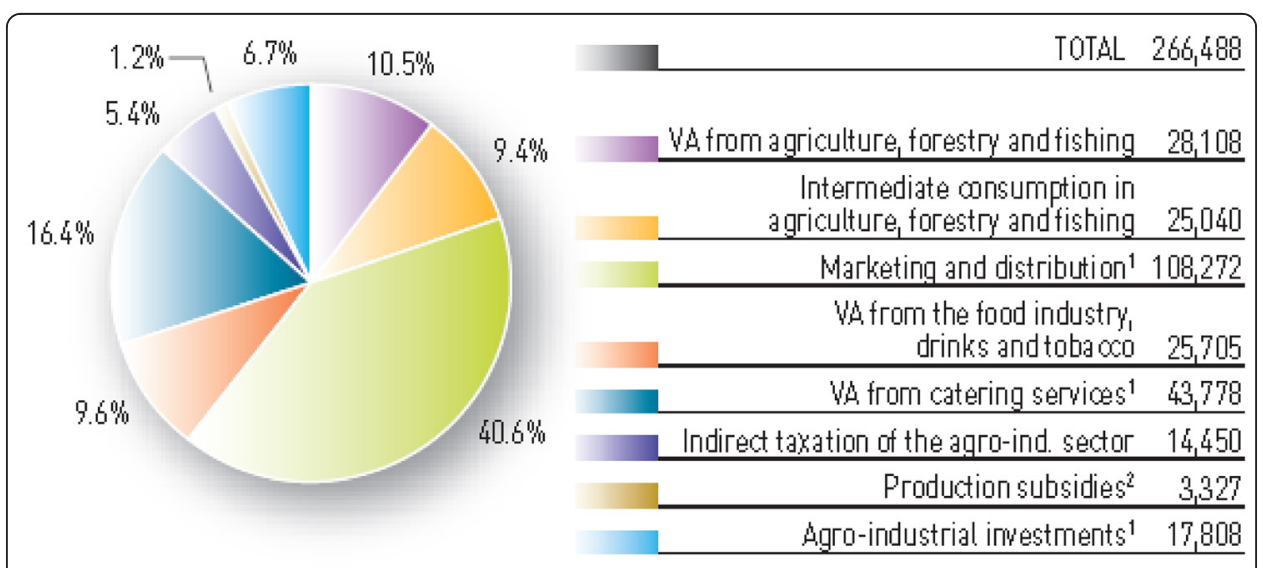

Fig. 3 Main components of agro-industrial system at basic prices (million euro) -2012. Source: INEA, 2014 


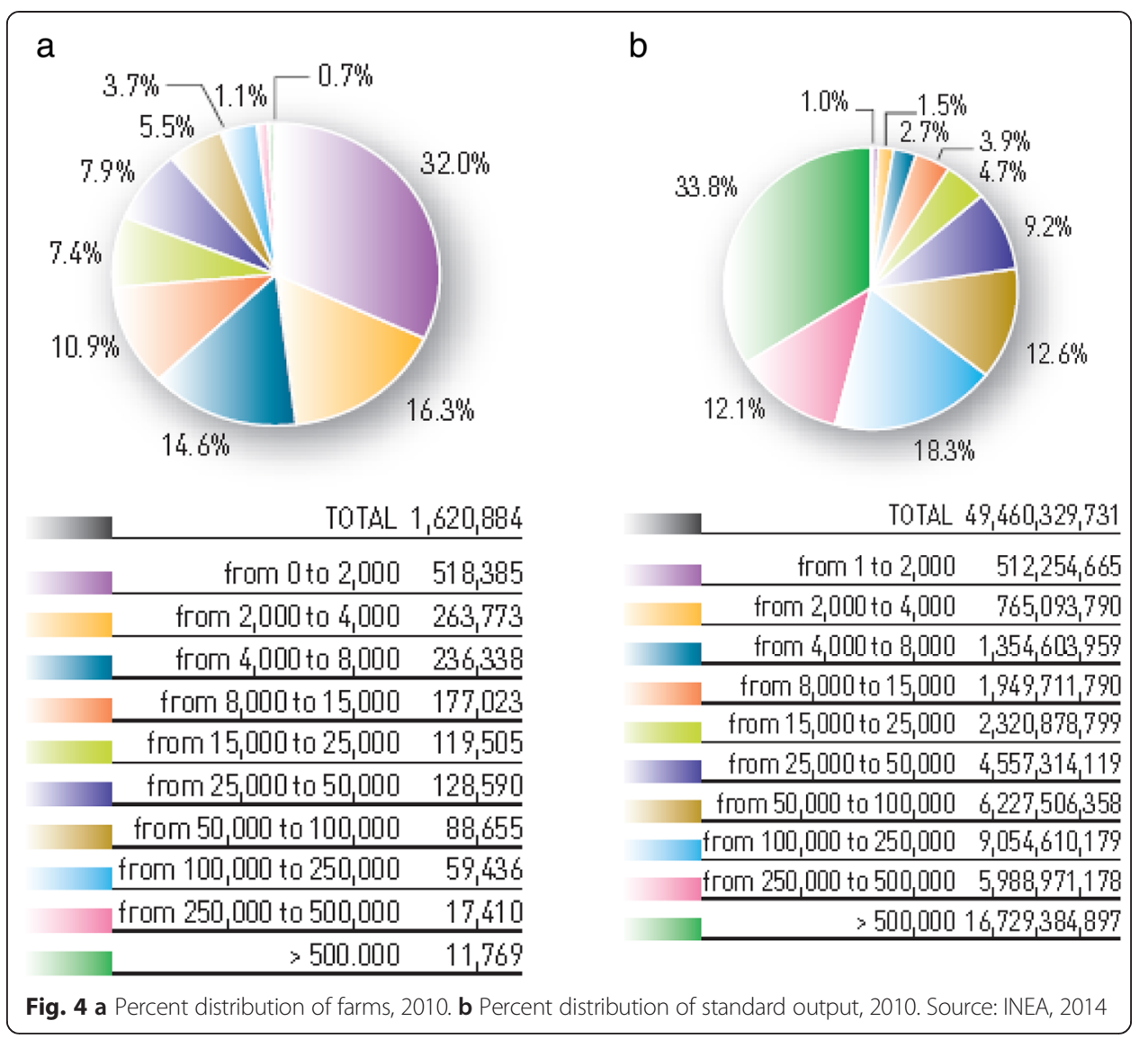

(Fig. 4b). It is clear that companies that have such a modest economic weight, although they play an important role in protecting the landscape, are mainly aimed at the production for self-consumption. Only 310,000 companies (19\% of the total) can be considered as real "business". These companies account for almost $90 \%$ of the value of the Italian standard production (whose total value amounts to approximately 49 billion and 500 million euro).

The structure of agricultural and livestock Italian companies is characterized by individual companies (96\%), mainly run by the owner or his family $(95.4 \%)$. The family plays a central role for the programming and the management of agriculture, as much as $76 \%$ of the total workforce comes from the owner and his family.

Most company leaders have a level of education less or equivalent to that of the middle school (71.5\%), only $0.8 \%$ seems to have a degree or diploma in agriculture. The title of the post-secondary school is not always connected to specific studies in agriculture: only $4.2 \%$ of the company leaders have a specific qualification in the sector, the remaining $24.3 \%$ have qualifications other than agriculture. Although a higher level of education can be found in larger companies, it should be said that even in these companies $(>500,000$ euro of standard production) most of the company leaders have a low degree of education that is almost half of the total number of farms (46\%).

\section{Access to finance for Italian SMEs}

Access to finance is one of the most important problems for Italian SMEs. Italy performs well below the EU average, with signs of increasing deterioration (Fig. 5). 


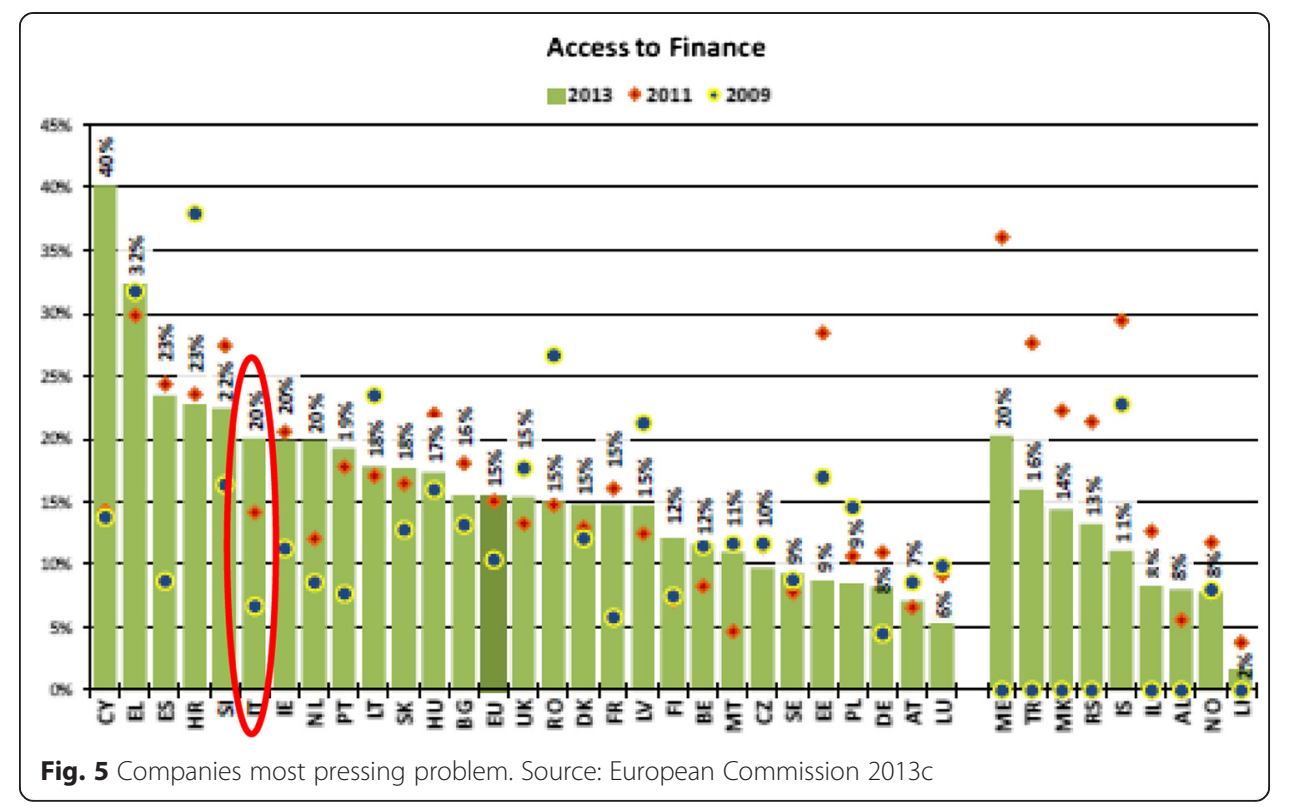

Banks are less willing to provide loans to SMEs, and this indicates a drying up of private sector financial support (Formisano et al. 2012). In line with the long payment times for public authorities, total invoice payment times are still one of the longest in Europe (117 days), double the EU average (53 days) (European Commission 2013b (Fig. 6).

Problems continue in the wider interest rate spread between small and large loans and in the absence of private equity and venture capital investors, especially for earlystage investments. Despite the efforts made by the government to sustain new and traditional forms of financial instruments, Italian SMEs still suffer from a chronic and structurally difficult access to finance. The main problems are:

- The increased administrative rigidity of banks in providing loans

- The higher differential rates between large companies firms and small and medium companies

\section{Methods}

In agreement with the European Commission SME definition, this paper considers a sample of small and medium companies located in Italy. This sample has been extracted from AIDA, a database of Bureau van Dijk, which contains economic and financial information with up to 8 years of history of more than 200,000 Italian companies. Before this analysis, this paper analyses the main problem related to access to finance for Italian small and medium companies.

An analysis of the main weaknesses in financing Italian agro-food SMEs is the basis for the research. Data was obtained through a survey of business companies. The research was carried out with CFOs, responsible for capital budgeting decisions. In order to achieve this goal, a total of 153 entrepreneurs-managers were targeted as potential respondents. Due to the nature of research, the study focused primarily on CFOs and managers who are involved in the capital budgeting decisions. 


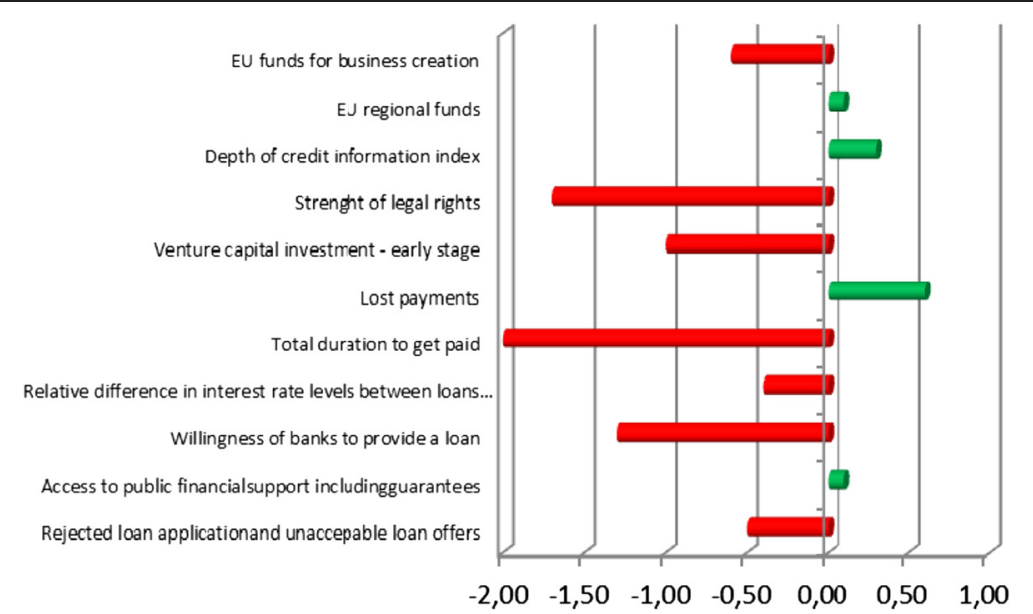

Fig. 6 Distance from the EU average (measured in standard deviation, EU average $=0$ ). Source: European Commission 2013c

The aim of pilot testing was to check the relevance of the questions before interviewing. Out of the 153-targeted interviews, a total of 80 interviews were successfully conducted. They provided a response rate of about $52 \%$.

\section{Results and discussion}

The following section discusses the main findings and results of the survey on capital budgeting techniques used by Italian companies. The first classification refers to the size of the business and the sector of the companies involved. From the total of 80 respondents, $28.75 \%$ qualified as medium enterprises, and the remaining $71.25 \%$ were categorized as small businesses.

The objective of the survey was to find out whether there was any relationship between financial decision makers and their level of qualification. In fact, there is a different involvement of respondents to the survey. Figure 7 shows the formal educational qualifications of the decision makers of the respondents.

The research highlights that the decision makers that did have a high school diploma mainly used bank loans or overdrafts as compared to those that received formal training. However, an in-depth analysis revealed that the use of much more sophisticated financial instruments (factoring, leasing, etc.) was much more popular with those who received formal accounting-finance training. A closer look at the companies that used more than one source of finance indicates that the majority of them belonged to the post graduate category.

Another important step of the research was the analysis of the responses given per category of firms. The results confirm the theory that SMEs have a preference for financial sources: bank loans. In fact, about $70 \%$ used bank loans or overdrafts, and as companies increase in size, they begin to use more financial sources.

External financial sources present an important cost: interests. In our interviews, we asked CFOs for the interest rates. This aspect is fundamental because this is a signal of entrepreneurial awareness in financial choices. The research highlights that the SMEs decision makers are not particularly aware of the interest rates on loans. They consider an interest rate as a fixed amount, but this is a crude approximation to reality. 


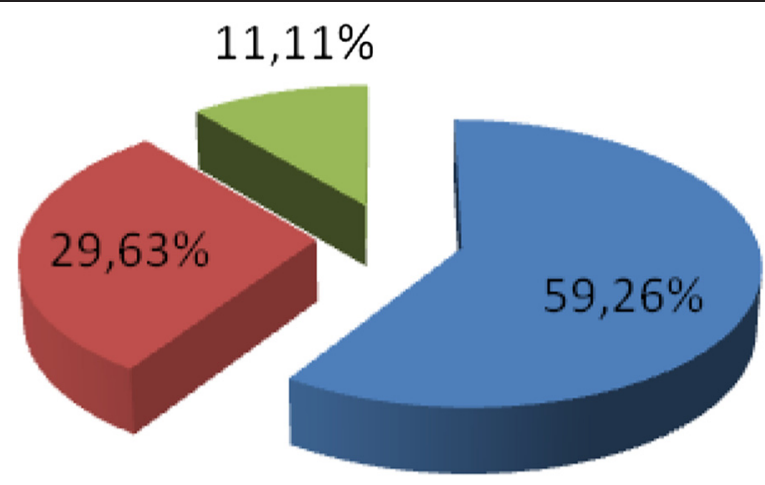

High School Diploma

Bachelor Degree

Post Graduate

Fig. 7 Qualifications of personnel. Source: author's calculation

Decision makers play a key role in financial choices. Different organizations use different decision makers to make their financial choices. Table 5 shows that decision makers are responsible for the selection of better financial sources according to the size of the companies.

The results above show that about $75 \%$ of the business owners are directly responsible for the choices of financial sources. Furthermore, the results suggest that different business level managers have limited influence on this decision-making process. However, the influence increases with the increase in the size of the company. It appears that, where present, the finance section had an important effect in all decisions making scenarios.

A similar view can be expressed with regard to the role played by teams. A possible explanation is linked to the nature of small businesses. The majority of the interviewees in small companies had limited operational structures, generally associated with larger corporations. This may be a reason why owners defined financial choices in small companies. However, the same reason cannot be attributed to larger enterprises. In fact, they have more formalized structures and large work forces.

\section{Conclusions and research limitations}

The research has combined primary data with secondary data to reach specific findings regarding the nature of choices of financial sources of agro-food Italian companies.

Table 5 Decision makers

\begin{tabular}{lll}
\hline Decision makers & Small (\%) & Medium (\%) \\
\hline Owner & 79 & 62 \\
Chief financial officer & 8 & 24 \\
Team decision & 13 & 14 \\
\hline
\end{tabular}

Source: author's calculation 
Particularly, in this research, two different variables were considered: the impact of the business size and the level of education of decision makers.

This research has proved that financial decisions are complex, but underestimated by SMEs. In fact, in these companies, owners are directly responsible. In most cases of the companies included in the sample, the decisions makers have taken choices without appropriate training (Rossi et al. 2012).

In terms of prescriptive conclusions, the obvious advice is to adopt proper strategic financial processes, especially for small companies. Beyond this and more constructively, research recommends greater attention towards growth and the achievement of proportional cost economies (scale and scope).

With regard to the choices of financial sources, the structural analysis of this research provides the low capital in companies and high financial exposure, generating a double negative effect: firstly, the high interest expenses erode the low operating revenue; and secondly, a vulnerability result of many local high-quality agro-food companies to acquisitions from larger international producers.

Research has also highlighted a deficiency regarding the degree and nature of investments. Specifically, the need for investment in tangible assets to be supported by investments in research and development was pinpointed: investments with the objective of product and process innovations; brand repositioning along a higher (consumer perceived) quality; and market and consumer knowledge towards development of ideas, creativity, originality and consumer-focused tactics.

The limitations of the paper are the result of its very nature: it is a largely conceptual paper. Empirical research is therefore needed to test and validate the essentially preliminary framework developed and the (well-based) assumptions made towards its development. Particularly, the most important limit is the definition of the company size that was based only on the number of employees. Other indicators of business size such as capital employed and turnover were not considered.

This research has an exploratory aim, and its findings are far from definite. On the contrary, they represent a starting point, a base for further research and analysis. For this reason, the empirical results should be interpreted in view of some limitations: the sample of companies is random and does not fully conform to the criteria of statistical representation; the sample of companies could be expanded numerically.

The above findings nonetheless, do require further research towards greater validation and refinement on the one hand (zoom in), and exploration of the wider perspectives presented on the other (zoom out). More specifically, it is recommended that research is undertaken to investigate more accurately and in greater depth, the various aspects of the agro-businesses; but also do so for specific sub-categories (by type, size, area, etc.). However, the complexity of the subjects, as well as the role of the human factor involved additionally calls for further research of a qualitative nature that will shed light on the less tangible, 'softer' aspects of agro-business management. 
agro-industrial system" section was written by Nadia Oliva; "Product of designated origin" was written by Matteo Rossi and Nadia Oliva; whereas "Conclusions and research limitations" section is the result of the common elaboration by the authors.

\section{Author details}

${ }^{1}$ University of Sannio, Via delle Puglie, 82, 82100 Benevento, Italy. ${ }^{2}$ Link Campus University, Via Nomentana, 335, 00162 Rome, Italy. ${ }^{3}$ University of Palermo, Viale delle Scienze, 4, 90128 Palermo, Italy. ${ }^{4}$ Giustino Fortunato University, Via Delcogliano, 12, 82100 Benevento, Italy.

Received: 3 November 2015 Accepted: 8 December 2015

Published online: 13 January 2016

\section{References}

Auberbach, A. J. (1985). Real determinants of corporate leverage. In B. M. Friedman (Ed.), Corporate capital structures in the United States, 1985 (pp. 301-322). Chicago: University of Chicago Press.

Barclay, M. J., Smith, C. W., \& Watts, R. L. (1995). The determinants of corporate leverage and dividend policies. Journal of Applied Corporate Finance, 7(4), 4-19.

Bradley, M., Jarrell, G. A., \& Kim, E. H. (1984). On the existence of an optimal capital structure: theory and evidence. The Journal of Finance, 39(3), 857-878.

Calcagnini, G., \& lacobucci, D. (1997). Small firm investment and financing decisions: an option value approach. Small Business Economics, 9(6), 491-502.

Chen, L. H., Lensink, R., \& Sterken, E. (1998). The determinants of capital structure: evidence from Dutch panel data. Berlin: European Economic Association Annual Congress.

Chittenden, F., Hall, G., \& Hutchinson, P. (1996). Small firm growth, access to capital markets and financial structure: review of issues and an empirical investigation. Small Business Economics, 8(1), 59-67.

Constand, R. L., Osteryoung, J. S., \& Nast, D. A. (1989). Asset-based financing and the determinants of capital structure in the small firm'. In R. Yazdipour (Ed.), Advances in small business finance, 1991 (pp. 29-45). Boston: Kluwer Academic Publishers.

Crescimanno, M., Galati, A., Siggia, D., \& Tinervia, S. (2015). Web-sites quality and business performance: an empirical investigation in the Sicilian wineries". In D. Vrontis, G. Sakka, \& M. Amirkhanpour (Eds.), Management innovation and entrepreneurship. A global perspective (pp. 129-151). Newcastle: Cambridge Scholars Publishing.

European Commission (2013a). 2013 SBA Fact Sheet - ITALY. Available at http:/www.publicpolicy.it/wp-content/ uploads/2013/11/italy_en.pdf Accessed date 15 November 2015.

European Commission (2013b). "A recovery on the horizon? Annual report on European SME's 2012/2013". Available at http://th.enterprise-europe-germany.de/public/uploads/een-th/downloads/annual-report-smes-2013_en.pdf Accessed date 15 November 2015.

European Commission (2013c). "2013 SMEs' access to finance survey". Available at http://www.infocontinuaterzosettore. it/wp-content/uploads/allegati/2013-safe-analytical-report_en.pdf Accessed date 15 November 2015.

Formisano, V., Russo, G., \& Lombardi, R. (2012). A service dominant logic for banking services. Mercati e Competitività, 1, 81-95.

Friend, I., \& Hasbrouck, J. (1988). Determinants of capital structure. In A. Chen (Ed.), Research in finance (Vol. 7, pp. 1-19). New York: JAl Press Inc.

Graham, J. R. (1996). Debt and the marginal tax rate. Journal of Financial Economics, 41(1), 41-73.

Hamilton, R. T., \& Fox, M. A. (1998). The financing preferences of small firm owners. International Journal of Entrepreneurial Behaviour \& Research, 4(3), 239-248.

Holmes, S., \& Kent, P. (1991). An empirical analysis of the financial structure of small and large Australian manufacturing enterprises. The Journal of Small Business Finance, 1(2), 141-154.

INEA (2014). Italian Agriculture in Figures 2013, Rome:INEA.

ISTAT (2014). Quality agro-food products—year 2013, Rome:ISTAT.

Jordan, J., Lowe, J., \& Taylor, P. (1998). Strategy and financial policy in UK small firms. Journal of Business Finance \& Accounting, 25, 1-27.

Lasrado, L. A. (2013). Crowd funding in Finland - a new alternative disruptive funding instrument for businesses. Tampere University of Technology: Master of Science Thesis. Available at https:/dspace.cc.tut.fi/dpub/bitstream/handle/ 123456789/21784/Lasrado.pdf? sequence=3.

López, J. G., \& Aybar, C. A. (2000). Empirical approach to the financial behaviour of small and medium sized companies. Small Business Economics, 14(1), 55-63.

Michaelas, N., Chittenden, F., \& Poutziouris, P. (1999). Financial policy and capital structure choice in UK SMEs: empirical evidence from company panel data. Small Business Economics, 12(2), 113-130.

Modigliani, F., \& Miller, M. H. (1958). The cost of capital, corporation finance and the theory of investment. The American Economic Review, XLVIII(3), 261-297.

Modigliani, F., \& Miller, M. H. (1963). Corporate income taxes and the cost of capital: a correction. The American Economic Review, 53(3), 433-443.

Myers, S. C., \& Majluf, N. S. (1984). Corporate financing and investment decisions when firms have information that investors do not have. Journal of Financial Economics, 13, 187-221.

Rajan, R. G., \& Zingales, L. (1995). What do we know about capital structure? Some evidence from international data. The Journal of Finance, 50(5), 1.421-1.460.

Rossi, M. (2014). Capital structure of small and medium enterprises: the Italian case. International Journal of Globalisation and Small Business, 6(2), 130-144

Rossi, M. (2015). The role of venture capital funds in financing innovation in Italy. Constraints and challenges for innovative small firms. International Journal of Globalisation and Small Business, 7(2), 162-180.

Rossi, M., Vrontis, D., \& Thrassou, A. (2012). Wine business in a changing competitive environment-strategic and financial choices of Campania wine firms. Int Journal of Business and Globalisation, 8(1), 112-130.

Rossi, M., Vrontis, D., \& Thrassou, A. (2014). Agro business in a changing competitive environment-Campania firms' strategic, marketing and financial choices. World Review of Entrepreneurship, Management and Sustainable Development, 10(2/3), 312-333. doi:10.1504/WREMSD.2014.060389. 
Titman, S., \& Wessels, R. (1988). The determinants of capital structure choice. The Journal of Finance, 43(1), 1-19.

Trequattrini, R., Russo, G., \& Lombardi, R. (2012). The crisis of company networks and tools for its prediction. International Business Research, 5(10), 46-55.

van der Wijst, D. (1989) 'Financial structure in small business. Theory, tests and applications', Lecture Notes in Economics and Mathematical Systems, No. 320, Berlin:Springer-Verlag.

Wald, J. K. (1999). How firm characteristics affect capital structure: an international comparison. The Journal of Financial Research, 22(2), 161-187.

Walker, D. A. (1989a). Financing the small firm, small business economics. Fall, 1(2), 285-296.

Walker, D. A. (1989b). An empirical analysis of financing the small firm. In R. Yazdipour (Ed.), Advances in small business finance, 1991 (pp. s47-61). Dordrecht: Kluwer Academic Publishers.

Zingales, L. (2000). In search of new foundations. The Journal of Finance, LV(4), 1623-1653.

Submit your manuscript to a SpringerOpen ${ }^{\circ}$ journal and benefit from:

- Convenient online submission

- Rigorous peer review

- Immediate publication on acceptance

- Open access: articles freely available online

- High visibility within the field

- Retaining the copyright to your article

Submit your next manuscript at $>$ springeropen.com 